\title{
ANALYSIS OF CREATINE KINASE ACTIVITY WITH EVALUATION OF PROTEIN EXPRESSION UNDER THE EFFECT OF HEAT AND HYDROGEN PEROXIDE
}

\author{
A. D. RAKHMETOV ${ }^{1}$, LEE SANG PIL ${ }^{2}$, L. I. OSTAPCHENKO', CHAE HO ZOON²
}

\author{
${ }^{1}$ Education and Science Center Institute of Biology Taras Shevchenko \\ National University of Kyiv, Ukraine; \\ ${ }^{2}$ Chonnam National University, Gwangju, South Korea; \\ e-mail: anar.rakhmetov@gmail.com
}

\begin{abstract}
Protein oxidation has detrimental effects on the brain functioning, which involves inhibition of the crucial enzyme, brain type creatine kinase (CKBB), responsible for the CK/phosphocreatine shuttle system. Here we demonstrate a susceptibility of CKBB to several ordinary stressors. In our study enzymatic activity of purified recombinant brain-type creatine kinase was evaluated. We assayed $30 \mathrm{nM}$ concentration of CKBB under normal and stress conditions. In the direction of phosphocreatine formation hydrogen peroxide and heat treatments altered CKBB activity down to 26 and 14\%, respectively. Also, examination of immunoblotted membrane patterns by SDS-PAGE electrophoresis and western blot analysis showed a decrease in expression levels of intrinsic CKBB enzyme in HeLa and A549 cells. Hence, our results clearly show that cytosolic CKBB is extremely sensitive to oxidative stress and heat induced inactivation. Therefore, due to its susceptibility, this enzyme may be defined as a potential target in brain damage.
\end{abstract}

Key word s: activity of brain creatine kinase, stress, hydrogen peroxide, heat inactivation.

A mple energy supply is crucial for proper functioning of the brain tissue. The main role in providing constant ATP/ADP ratio belongs to creatine kinase (CK; adenosine-5'triphosphokinase; EC 2.7.3.2). In the brain, two isoforms of creatine kinase are present, cytosolic brain creatine kinase (CKBB) and mitochondrial ubiquitous CK (MiCK) [1]. CKBB is a homodimer enzyme, catalyzing reversible transfer of $\gamma$-phosphate group from ATP molecule to creatine, with formation of buffering phosphocreatine (PCr) and ADP. Domains associated with ATP production and consumption are predominantly connected by phosphocreatine/ creatine network [2]. CK isoforms accumulate $\mathrm{PCr}$ within the cell to high concentrations and uses this molecule in the reverse reaction to regenerate pools of ATP under increased workload [3].

Impairment of creatine kinase activity induces radical changes in mice's phenotype, where the experimental subjects had permanent reduction of body weight, detrimental spatial learning, vestibular dysfunction and partially abnormal morphology of the hippocampal brain structure [1]. Knockout mice lacking $\mathrm{CKBB}$ show deficiencies in learning and memory [4]. Inhibition of CKBB activity is impli- cated in the pathogenesis in a number of diseases, particularly in the brain $[5,6]$. Therefore, alterations in CK functioning have been proposed to induce development of detrimental CNS abnormalities with altered energy metabolism and may represent an important step of neurodegenerative pathway that leads to disorder progression $[7,8]$.

Generation of oxygen free radicals have been implicated in mediating various pathological processes. It is reported that functioning of CK is extremely affected by reactive oxygen species $[5,9]$. Few studies showed that susceptibility of CK to $\mathrm{H}_{2} \mathrm{O}_{2}$ is controlled by oxidation of a cysteinyl residue $\left(\mathrm{Cys}^{282}\right)$ that plays a critical role in substrate binding. Substitution of $\mathrm{Cys}^{282}$ residue for serine resulted in a 500-fold activity decrease of CK [10]. Cystein 283 was identified as a main target for chemical modification [11]. Thermal inactivation of muscle creatine kinases was studied by Lyubarev [12]. The author confirmed the two-state irreversible aggregation of CKMM with differential adiabatic scanning microcalorimetry method, which was previously proposed by Kurganov [13]. Studies by Gao, have also supported calorimetrical irreversibility of human CKBB. It was proposed that the thermal inactiva- 
tion of creatine kinase involves a hierarchy of structural transitions [14]. Uniquely, thermally inactivated muscle creatine kinase exhibited much higher stability than that of CKBB. However, when CKMM is aggregated, no reactivation state can be observed, while human CKBB has shown partial reversibility at temperatures above $55^{\circ} \mathrm{C}$. This can be explained by functional dissimilarities between two isoform's expression tissues.

With the established number of experimental papers demonstrating that brain type of creatine kinase is extremely crucial upon development of quite a few brain disorders [15, 7]; we have made a further attempt to evaluate the CKBB activity loss. With previously purified recombinant CKBB protein we determined the most favorable enzyme concentration of $30 \mathrm{nM}$. For experiments in vitro, overexpression of pCMV-Flag construct carrying CKBB insert was performed on two particular cell lines. The loss of CK enzyme activity is reported during progression of Alzheimer's and Huntington's disorders. Therefore, the overall research goal was to demonstrate susceptibility of the homodimeric brain type creatine kinase to physiological stimuli of hydrogen peroxide and heat inactivation.

\section{Materials and Methods}

Overexpression of CKBB in mammalian cell lines. For the in vitro detection of CKBB in HeLa and A549 cell we transfected cells with plasmids pCMV-Flag carrying CKBB gene insert. Construction of recombinant plasmid was done with reference to the procedures described previously [16]. The plasmids harboring Flag-CKBB was transiently transfected into $60 \mathrm{~mm}$ dish cultured with A549 or HeLa cells using Lipofectamine/Plus Reagents (Invitrogen) according to the manufacture's protocol. Medium supplemented with 10\% FBS was changed for FBS free medium to the transfected cells after 4-6 hours of incubation.

Cell cultures. Cell lines used for transfection, A549 (human lung adenocarcinoma cells) and HeLa (human cervical carcinoma cells) were purchased from American Type Culture Collection (ATCC). A549 cells were cultured in RPMI 1640 medium (WelGENE), HeLa cells in Dulbecco's modified Eagles medium (WelGENE), both supplemented with $10 \%$ fetal bovine serum (FBS, WelGENE) and $1 \%$ antibiotic-antimycotic (Invitrogen). The maintained environment was adjusted to $37^{\circ} \mathrm{C}$ in a humidified atmosphere containing $5 \%$ (vol $/ \mathrm{vol}) \mathrm{CO}_{2}$.
Cells were passaged every two-three days at 70-80\% confluence. The plasmids harboring Flag-CKBB, constructs were transiently transfected into $60 \mathrm{~mm}$ dish cultured with A549 or HeLa cells using Lipofectamine/Plus Reagents (Invitrogen) according to the manufacture's protocol. Medium supplemented with 10\% FBS was changed for FBS free medium to the transfected cells after 4-6 hours of incubation.

SDS-PAGE electrophoresis. Protein samples were prepared with $2 \mathrm{x}$ or $5 \mathrm{x}$ SDS-PAGE sample buffer (10 mM Tris-HCl, pH 6.8, 4\% SDS, $10 \%$ $\beta$-mercaptoethanol, $20 \%$ glycerol, $0.2 \%$ bromphenol blue) and cooked at $95{ }^{\circ} \mathrm{C}$ for $5 \mathrm{~min}$. For the SDSPAGE were used $12 \%$ acrylamide separating gel and $5 \%$ stacking gel. Electrophoresis was carried out at a 70-150 V range (Power Pack 1000, Bio-Rad) using 1xSDS-PAGE buffer. After electrophoresis, the gel was either stained in a Coomassie Brilliant Blue solution or immunoblotted with specific antibodies.

Specific creatine kinase activity assay. Recombinant $\mathrm{CKBB}$ was overexpressed and purified according to the procedures described in the previous study [17]. CKBB activity was determined in the forward direction (phosphocreatine formation) according to the pH-colorimetry method [18] with some modifications.

$$
\mathrm{Cr}+\mathrm{ATP} \stackrel{\text { Creatine kinase }}{\longleftrightarrow} \mathrm{PCr}+\mathrm{ADP},
$$

where $\mathrm{Cr}$ - creatine, $\mathrm{PCr}$ - creatine phosphate.

The enzymatic activity was monitored by the absorption at the excitation wavelength of $597 \mathrm{~nm}$ with a Jasco V-530 UV-visible spectrophotometer (Jasco, Tokyo, Japan). Assay mixture, 600 $\mu \mathrm{l}$, contained $24 \mathrm{mM}$ creatine, $4 \mathrm{mM}$ ATP, $5 \mathrm{mM} \mathrm{Mg}^{2+}$, and $0.01 \%$ Thymol Blue, in $5 \mathrm{mM}$ Glycine-NaOH buffer, $\mathrm{pH}$ 9.0. The final protein concentration of the brain creatine kinase was $30 \mathrm{nM}$. The equation to calculate the enzyme activity of creatine kinase was used as follows (with accordance to Yao, 1982).

$$
U=\frac{1.3 \times \Delta A_{597} \times \Delta V_{A} \times \text { Dilution ratio }}{C \times V_{B}},
$$

where $U$ - specific activity; 1.3 - converting coefficient; $V_{A}$ - the volume of substrate; $V_{B}$ - the volume of enzyme solution; $C$ - the concentration of enzyme solution.

Thermal and $\mathrm{H}_{2} \mathrm{O}_{2}$ mediated inactivation of $C K B B$. Thermal inactivation was carried out by incubating the purified enzyme diluted in Glycine$\mathrm{NaOH}$ (pH 9.0) buffer at given temperatures for $10 \mathrm{~min}$. After heat treatment, the sample was cooled 
immediately on ice, and then the residual activity was measured at $25^{\circ} \mathrm{C}$.

$\mathrm{H}_{2} \mathrm{O}_{2}$ was added at final concentrations of 0.25 , 0.5 , and $1 \mathrm{mM}$ to creatine kinase samples diluted in Glycine- $\mathrm{NaOH}$ ( $\mathrm{pH} 9.0)$ buffer. Aliquots $(60 \mu \mathrm{l})$ were removed at specific time intervals $(10 \mathrm{~min})$ to determine CK activity. The remaining kinase activity of CKBB was calculated by fitting the initial linear range of the reaction progress curve. All data were expressed as a mean \pm SD. Differences between groups were examined for statistical significance using Student's paired test. $P<0.05$ denotes the presence of statistically significant difference. Statistical analysis of the obtained results was carried out using Microsoft Office Excel program package.

\section{Results and Discussions}

Since CKBB is differentially expressed and critical for ATP metabolism, we examined enzyme's potential to retain kinase activity affected by various stresses. Oxidative modifications have a major role in the pathogenesis of neurodegenerative disorders, regulated by protein and lipid oxidative modifications [20]. Studies on human muscle creatine kinase have confirmed that thermal irreversibility of the enzyme was reached under the temperature of $56^{\circ} \mathrm{C}$ [2]. Western blotting with the antibodies against CK isoenzyme using cell homogenate from HeLa cells identifies a single band of $43 \mathrm{kDa}$. Brain homogenates from Alzheimer's patients show a decrease of CK activity by $86 \%$, whereas expression levels of the enzyme were down by $14 \%$ [7, 21]. Additionally it was shown that the exposure of CK isoenzymes in rat tissues (brain, heart, and muscles) to xanthine and xanthine oxidase or hydrogen peroxide resulted in a significant decrease in the activities of CK in a dose dependent fashion [22]. Due to the increasing number of papers suggesting a decrease of total CK activity in the brain tissue, majorly because of reactive oxygen species, it is intriguing to verify the susceptibility of CK protein under specific assay conditions $[7,8,19]$.

In our experiment, when recombinant brain creatine kinase was incubated with varying concentrations of hydrogen peroxide for $10 \mathrm{~min}$ at $25^{\circ} \mathrm{C}$, an inhibition of CKBB activity was registered. The decrease in the CKBB activities was by 17,58 , and $74 \%$; when the hydrogen peroxide concentrations were $0.25,0.5$, and $1.0 \mathrm{mM}$, respectively (Fig. 1). Effects of $\mathrm{H}_{2} \mathrm{O}_{2}$ were strong at high concentrations. These detrimental influences of hydrogen peroxide on functional activity of CK are supported by free radical inhibition of tissues specific CK presented by [22]. PCr and CK were found to be slightly decreased in skeletal muscles of mice with deficient cytosolic and mitochondrial CK activity [21]. In Alzheimer's disease, amyloid beta-peptide which induces generation of free radicals is thought to inhibit the oxidative sensitive enzyme CK and therefore causes neurodegeneration [30]. Besides hydrogen peroxide, cystine which is usually accumulated in lysosomes has pronounced effects on the CK activity [23]. Release of cystine from lysosome induces oxidative stress that generates oxidized forms of CKBB (OCKBB). However, O-CKBB is not the major reason for the inactivation of CKBB. Disulfide bond between CKBB generated mutants C74S and C254S demonstrated a limited contribution to the inactivation of CKBB induced by cystine. Therefore, the author had concluded that the generation of O-CKBB was not the major reason for the inactivation of CKBB, in fact the inactivation of CKBB by cystine was caused by the modification of conserved Cys 283 [23]. The active sites of CK include very essential cysteine amino acids which are possible targets for oxygen free radicals and modification of these groups can cause reduction in enzymatic activity of CKs [22, 24]. Our results therefore support a high susceptibility of CK to oxidative factors confirmed by other experimental studies [22-24].

The thermostability of brain isoform of creatine kinase was evaluated by a residual activity retained after heating the enzyme solutions at given temperatures for $10 \mathrm{~min}$. We showed that in the direction of phosphocreatine formation heat treatment significantly decreases CKBB kinase activity (Fig. 1). Results acquired from the specific activity assay revealed a marked inhibition of CKBB by 36, 57 , and $86 \%$ in the reaction mixture with treatment temperatures of 38,40 and $42{ }^{\circ} \mathrm{C}$. While comparing the results from hydrogen peroxide and heat inactivation reactions we observe a slightly more inhibited CKBB activity under the heat treatment conditions. This difference may arise due to the separate inactivation mechanisms. The parameters summarized in Table were consistent with those of CK from other studies [25]. CK possesses four cysteine residues and only one of them is believed to be essential for catalytic activity, where the other three are thought to be involved in CK folding [25-27]. According to [2] muscle isoform of CK could retain its activity at temperatures below $50{ }^{\circ} \mathrm{C}$ and being completely in- 
A

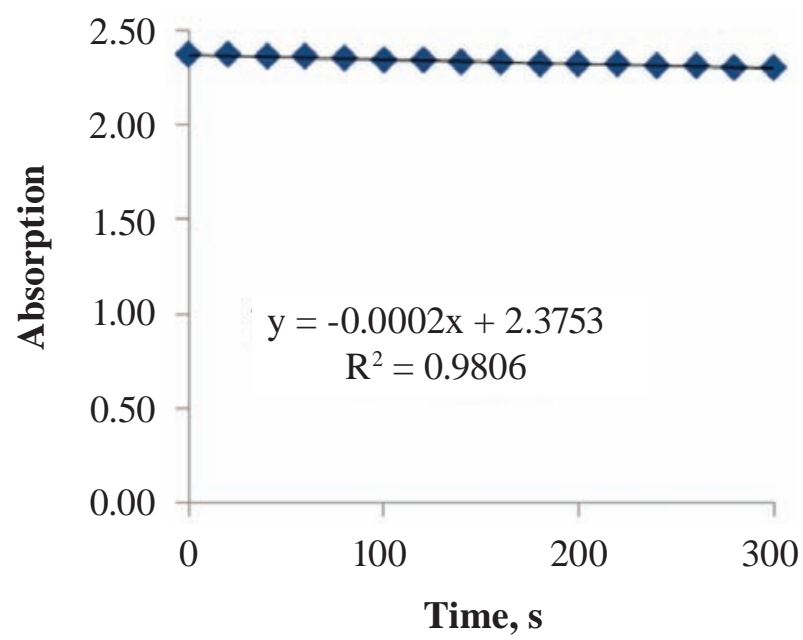

C

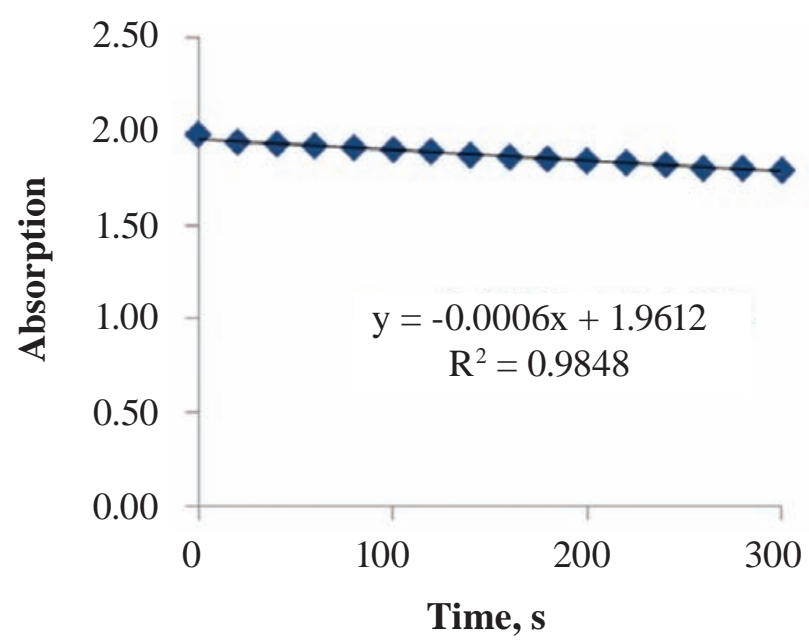

B

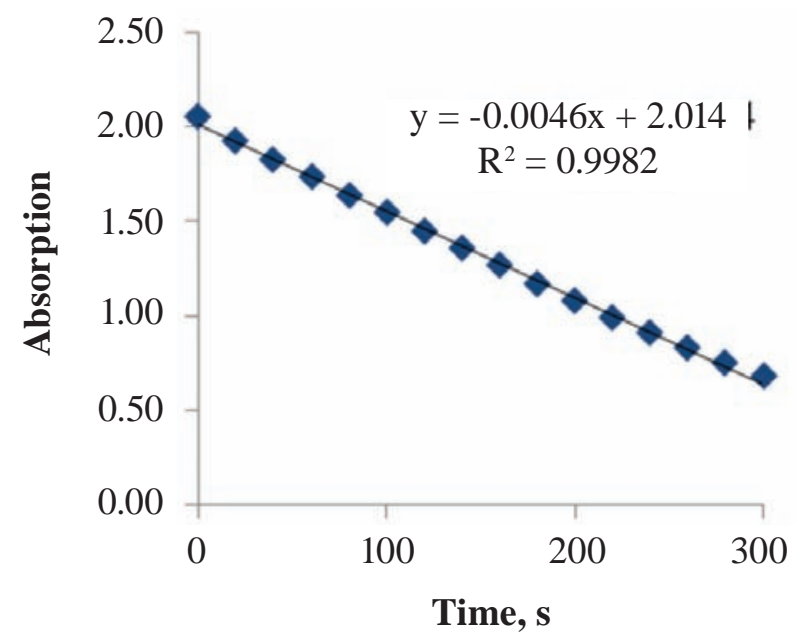

D

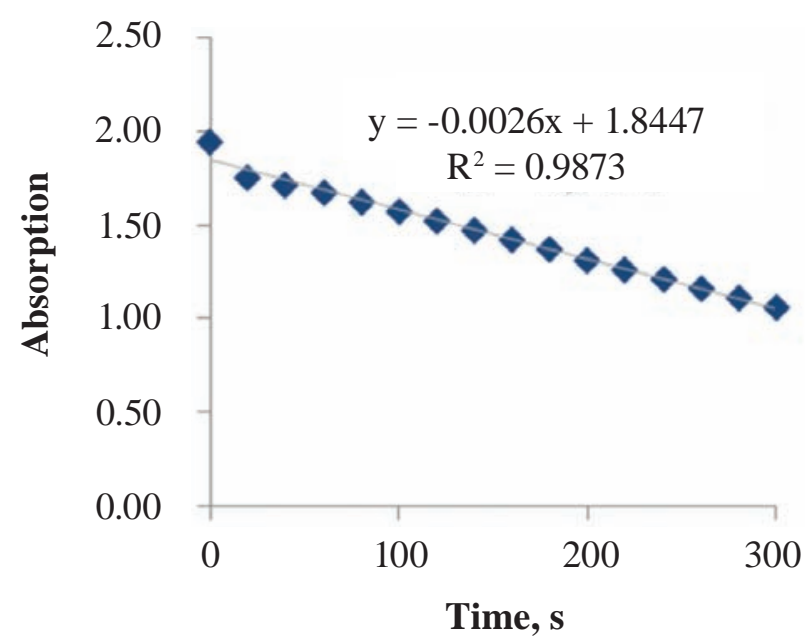

Fig. 1. Combined chart of residual activity of inactivated creatine kinase (CK) under heat and $\mathrm{H}_{2} \mathrm{O}_{2}$ treatment. Where $A$ - control chart with no CK enzyme; $B-30 \mathrm{nMCK}$ in reaction buffer; $C-C K B B$ incubated for $10 \mathrm{~min}$

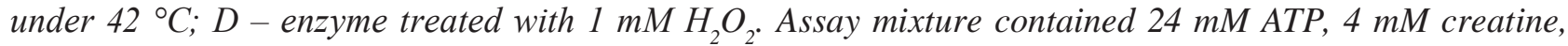
$\mathrm{MgCl}_{2}$, thymol blue indicator dissolved in the glycerol-NaOH buffer with adjusted $\mathrm{pH}$ to 9.0. Assay conditions were adjusted under the room temperature of $25^{\circ} \mathrm{C}$. Each measurement was performed in triplicates. $P<0.05$ (paired t-test)

activated after heat treatment at temperatures above $62{ }^{\circ} \mathrm{C}[28,29]$. Although, CKBB has a high percentage of the primary sequence similarity with CKMM, the thermal stability of human CKBB is substantially lower than that of CKMM, and the midpoint temperatures of thermal inactivation decreased about $15{ }^{\circ} \mathrm{C}$ [2]. Our results suggest that recombinant CKBB began to be partially inactivated after 10 min heat-treatment at $38{ }^{\circ} \mathrm{C}$, a temperature close to the normal body temperature. As reported by [2] human CKBB was fully inactivated at temperatures above $48^{\circ} \mathrm{C}$.

On the other hand, thermally inactivated CKBB has been shown to have better results on activity recovery than CKMM. Up to $>60 \%$ of activity could be regained after reactivation on ice for $12 \mathrm{~h}$ for the enzymes treated at temperatures above $50{ }^{\circ} \mathrm{C}$ [2]. In the case of human CKMM a higher thermal stability is essential to fulfill its in vivo function to supply ATP to myosin during muscle contraction. Where, 
Specific activity calculated for thermal and hydrogen peroxide inactivation of CK enzyme. Data were presented as a Mean \pm S.D. $(n=3)$

\begin{tabular}{l|c|c}
\hline \multicolumn{1}{c|}{ Condition } & CK activity $(\mu \mathrm{M} / \mathrm{min} \cdot \mathrm{mg})$ & Relative activity, \% \\
\hline Control $\left(25^{\circ} \mathrm{C}\right)$ & $85.36 \pm 0.52$ & 100 \\
$38{ }^{\circ} \mathrm{C}$ & $54.71 \pm 2.12$ & 64.11 \\
$40^{\circ} \mathrm{C}$ & $36.74 \pm 0.46$ & 43.21 \\
$42^{\circ} \mathrm{C}$ & $12.48 \pm 1.95$ & 14.63 \\
$\mathrm{Control}\left(25^{\circ} \mathrm{C}\right)$ & $85.56 \pm 0.86$ & 100 \\
$0,25 \mathrm{mM}$ & $62.70 \pm 0.92$ & 73.28 \\
$0,5 \mathrm{mM}$ & $36.14 \pm 0.35$ & 42.24 \\
$1 \mathrm{mM}$ & $22.56 \pm 3.20$ & 26.37 \\
\hline
\end{tabular}

CKBB is distributed in vital organs and tissues with high energy demand, such as the brain and nervous system. Thus, it is possible that the relatively low stability and high reversibility may help the cells to control energy metabolism and protect tissues against pathological conditions [2].

Also, to support our assay data in vitro we applied the same heat and hydrogen peroxide stresses to overexpressed A549 and HeLa cells with pCMVFLAG tagged plasmid harboring CKBB insert. CKBB antibodies raised against rabbit were used to probe blotted nitrocellulose membranes. In the case of hydrogen peroxide treatment results have demonstrated reduced levels of CKBB in the wholecell lysate compared to untreated HeLa and A549 cells and GAPDH expression controls. Where the

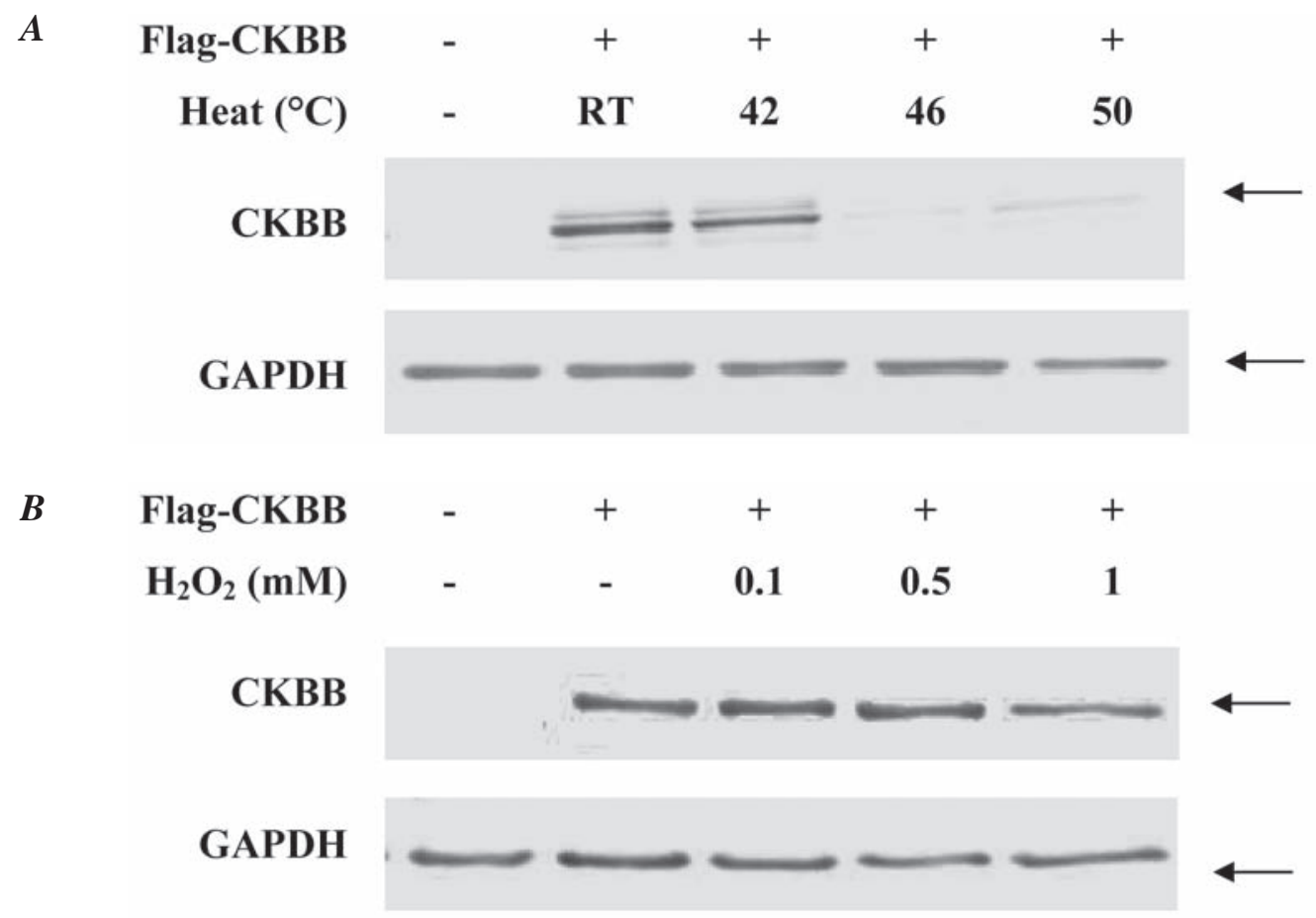

Fig. 2. Heat and hydrogen peroxide treated A549 cell lysates containing overexpressed CKBB protein. Cells were transiently transfected with the Flag-tagged plasmids carrying CKBB insert. Temperature and hydrogen peroxide incubated A549 cells were washed with PBS primarily to the harvesting and centrifugation. $10 \mu \mathrm{g}$ of protein was loaded onto the membrane well for SDS-page electrophoresis. Arrows indicate on the specific protein band of target CKBB and loading control GAPDH. Molecular mass of dimer CKBB corresponds to $43 \mathrm{kDa}$ 


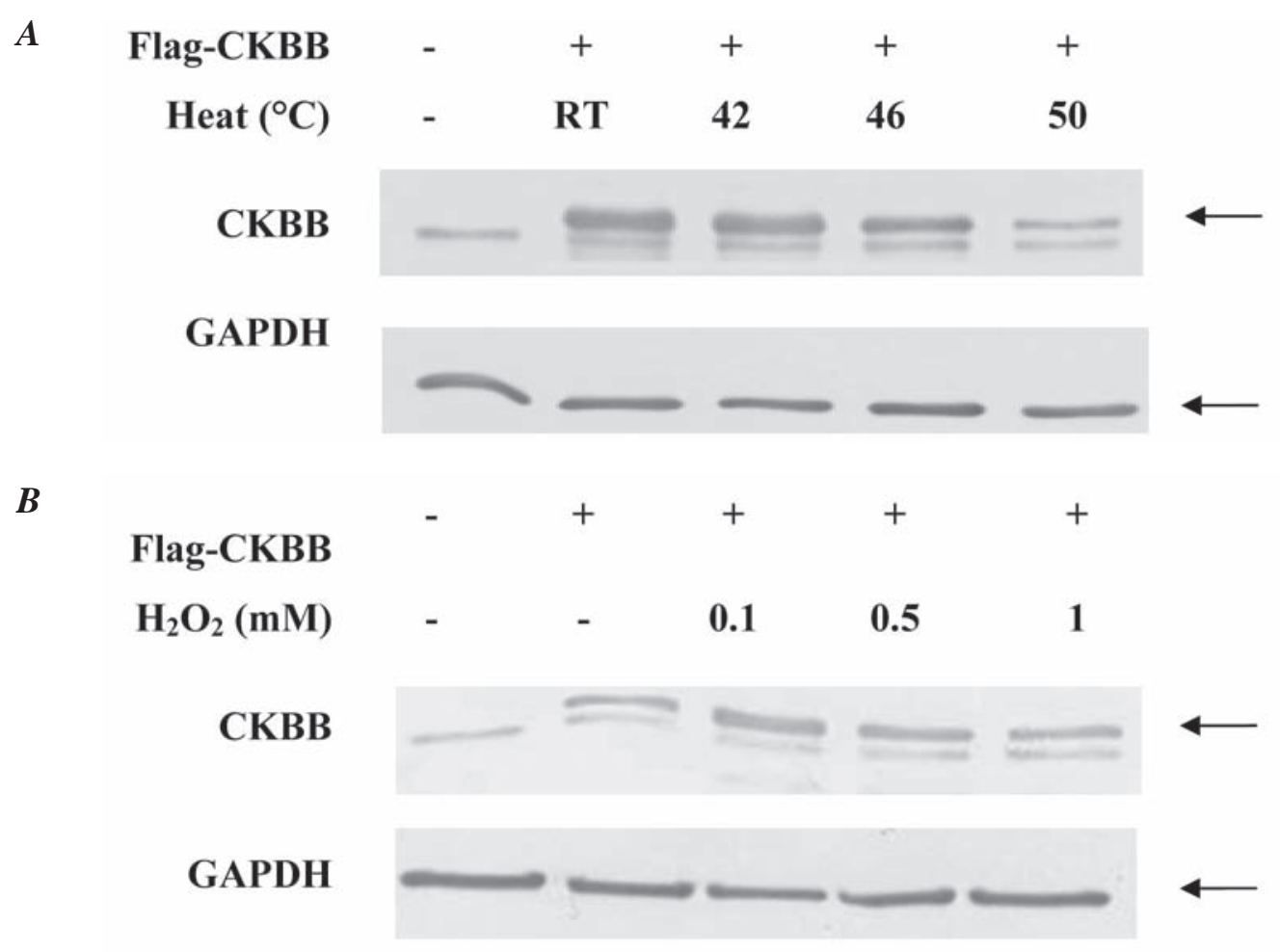

Fig. 3. Hydrogen peroxide and heat treated HeLa cell. Overexpressed CKBB indicated with arrows. Atreatment temperature were as labeled; $60 \mathrm{~mm}$ dishes with cell count of $1 \times 10^{6}$ were incubated for 10 min with carefully adjusted temperatures. $B$ - hydrogen peroxide was added to the cell in concentrations as labeled. After $\mathrm{H}_{2} \mathrm{O}_{2}$ discarded cells were washed with PBS and harvested

$1 \mathrm{mM} \mathrm{H}_{2} \mathrm{O}_{2}$ concentration had the most detrimental effects. The CKBB level in the heat-treated cell fraction was even lower than that of hydrogen peroxide treated cells (Fig. 2, 3). These data were consistent with the results from creatine kinase activity assay measurements. In contrast, the CKBB levels in the whole cell lysate under both factors varied in HeLa and A549 cell line. This dissimilarity might have taken place due to the presence of intrinsically expressed CKBB in the HeLa cells.

In conclusion, we show that brain creatine kinase has low resistibility to outer factors of heat and hydrogen peroxide inactivation. This responsiveness is connected to the specific tissue distribution of the enzyme. In the case of brain tissue, structurally fragile compartment, functional proteins must possess high endurance capacity. There, CKBB demonstrates reliable results during recovery studies and therefore it is best suited for providing uninterrupted energy supply in the brain.

\section{АНАЛІЗ АКТИВНОСТІ КРЕАТИНКІНАЗИ ТА ОЦІНКА РІВНЯ ЕКСПРЕСІЇ ПРОТЕЇНУ ЗА ВПЛИВУ ПЕРОКСИДУ ВОДНЮ ТА ТЕМПЕРАТУРИ}
А. Д. Рахметов므 Лі Сан-Піль², Л. I. Остапченко ${ }^{1}$, Чає Хо-Зун

${ }^{1}$ Київський національний університет імені Тараса Шевченка, ННЦ «Інститут біології», Україна;

${ }^{2}$ Чоннамський національний університет, Кванджу, Південна Корея; e-mail: anar.rakhmetov@gmail.com

Окислення протеїнів виявляє руйнівний вплив на функціонування головного мозку, що пов'язано з інгібуванням ензиму креатинкінази головного мозку (ККГМ), який забезпечує синтез фосфокреатину за участю молекули АТР. Метою цієї роботи було вивчення впливу на сприйнятливість рекомбінантного протеїну 
ККГМ пероксиду водню та температури. Показано, що активність ККГМ у реакції формування фосфокреатину за впливу пероксиду водню $(1 \mathrm{MM})$ та температури $\left(42^{\circ} \mathrm{C}\right)$ була знижена на 26 та 14\% відповідно. Імуноблотинг мембран після SDS-PAGE електрофорезу i вестернблотинг показали зниження рівня експресії внутрішньоклітинної креатинкінази в клітинних лініях HeLa та A549. Одержані результати демонструють високу чутливість цитозольного ензиму до дії зовнішніх факторів. Така сприйнятливість ККГМ до дії стресу може бути визначена як можливий чинник розвитку порушень у діяльності головного мозку людини.

К л ючов і слов а: активність креатинкінази головного мозку, стрес, пероксид водню, тепловий шок.

\section{АНАЛИЗ АКТИВНОСТИ КРЕАТИНКИНАЗЫ И ОЦЕНКА УРОВНЯ ЭКСПРЕССИИ ПРОТЕИНА ПРИ ДЕЙСТВИИ ПЕРОКСИДА ВОДОРОДА И ТЕМПЕРАТУРЫ}

\section{А. Д. Рахметов ${ }^{1}$ Ли Сан-Пиль ${ }^{2}$ Л. И. Остапченко, Чае Хо- 3 Н $^{2}$}

${ }^{1}$ Киевский национальный университет имени Тараса Шевченко, УНЦ «Институт биологии», Украина;

${ }^{2}$ Чоннамский национальный университет, Кванджу, Южная Корея; e-mail: anar.rakhmetov@gmail.com

Окисление протеинов оказывает разрушительное влияние на функционирование головного мозга, что связано с ингибированием креатинкиназы - энзима головного мозга (ККГМ), который обеспечивает синтез фосфокреатина при участии молекулы АТР. Целью данной работы было изучение влияния на восприимчивость рекомбинантного протеина ККГМ температуры и пероксида водорода. Показано, что активность ККГМ в реакции формирования фосфокреатина при действии пероксида водорода $(1 \mathrm{MM})$ и температуры $\left(42^{\circ} \mathrm{C}\right)$ была снижена на 26 и $14 \%$ соответственно. Иммуноблоттинг мембран после SDS-PAGE электрофореза и вестерн-блоттинг показали снижение уровня экспрессии внутриклеточной креатинкиназы в клеточных линиях HeLa и A549. Полученные результаты демонстрируют высокую чувствительность цитозольного энзима к действию внешних факторов.
Такая восприимчивость ККГМ к воздействию стресса может быть определена как возможный фактор развития нарушений в деятельности головного мозга человека.

Ключевы е слова: активность креатинкиназы головного мозга, стресс, пероксид водорода, тепловой шок.

\section{References}

1. Streijger F., Pluk H., Oerlemans F., Beckers G., Bianco A. C., Ribeiro M. O., Wieringa B., Van der Zee C. E. Mice lacking brain-type creatine kinase activity show defective thermoregulation. Physiol. Behav. 2009;97(1):76-86.

2. Gao Y. S., Zhao T. J., Chen Z., Li C., Wang Y., Yan Y. B., Zhou H. M. Isoenzyme-specific thermostability of human cytosolic creatine kinase. Int. J. Biol. Macromol. 2010;47(1):27-32.

3. Ramirez Rios S., Lamarche F., CottetRousselle C., Klaus A., Tuerk R. Regulation of brain-type creatine kinase by AMP-activated protein kinase: interaction, phosphorylation and ER localization. Biochim. Biophys. Acta. 2014;1837(8):1271-1283.

4. Streijger F., Oerlemans F., Ellenbroek B. A., Jost C. R., Wieringa B., Van der Zee C. E. Structural and behavioural consequences of double deficiency for creatine kinases BCK and UbCKmit. Behav. Brain Res. 2005;157(2):219234.

5. Aksenov M., Aksenova M., Butterfield D. A., Markesbery W. R. Oxidative modification of creatine kinase BB in Alzheimer's disease brain. J. Neurochem. 2000;74(6):2520-2527.

6. Beal M. F. Energetics in the pathogenesis of neurodegenerative diseases. Trends Neurosci. 2000;23(7):298-304.

7. Bürklen T.S., Schlattner U., Homayouni R., Gough K., Rak M., Szeghalmi A., Wallimann T. The Creatine Kinase/Creatine Connection to Alzheimer's Disease: CK Inactivation, APPCK Complexes, and Focal Creatine Deposits. J. Biomed. Biotechnol. 2006;2006(3):1-11.

8. Hemmer W., Wallimann T. Functional aspects of creatine kinase in brain. Dev. Neurosci. 1993;15(3-5):249-260.

9. Konorev E. A., Hogg N., Kalyanaraman B. Rapid and irreversible inhibition of creatine kinase by peroxynitrite. FEBS Lett. 1998;427(2):171-174.

10. Kenyon G. L. Energy metabolism. Creatine kinase shapes up. Nature. 1996;381(6580):281-282. 
11. Horneman T., Rutishauser D., Wallimann T. Why is creatine kinase a dimer? Evidence for cooperativity between the two subunits. Biochim. Biophys. Acta. 2000;1480(1-2):365-373.

12. Lyubarev A. E., Kurganov B. I., Orlov V. N., Zhou H. M. Two-state irreversible thermal denaturation of muscle creatine kinase. Biophys. Chem. 1999;79(3):199-204.

13. Kurganov B. I., Lyubarev A. E., SanchezRuiz J. M., Shnyrov V. L. Analysis of differential scanning calorimetry data for proteins. Criteria of validity of one-step mechanism of irreversible protein denaturation. Biophys. Chem. 1997;69(2-3):125-135.

14. Gao Y. S., Su J. T., Yan Y. B. Sequential events in the irreversible thermal denaturation of human brain-type creatine kinase by spectroscopic methods. Int. J. Mol. Sci. 2010;11(7):2584-2896.

15. Aksenov M. Y., Aksenova M. V., Butterfield D. A., Geddes J. W., Markesbery W. R. Protein oxidation in the brain in Alzheimer's disease. Neuroscience. 2001;103(2):373-383.

16. Rakhmetov A. D., Li S. P., Ostapchenko L. U., Chae H. Z. Molecular Cloning of Human Brain-Type Creatine Kinase Gene into Bacteria Expression Vectors PET-17B, PET-14B and Flag Tagged Mammalian Expression Vector PCMV. Vistnyk KNU. 2013;64(2):58-61.

17. Rakhmetov A. D., Li S. P., Ostapchenko L. U., Chae H. Z. Purification and polyclonal antibody production of recombinant brain-type creatine kinase. Russian J. Biopharmaceuticals. 2014;6(2):7-11.

18. Yao Q. Z., Hou L. X., Zhou H. M., Zho C. G. Conformational changes of creatine kinase during guanidine denaturation. Sci. Sin. 1982;25(11):1186-1193.

19. WallimannT., Takarska-Schlattner M., Schlattner U. The creatine kinase system and pleiotropic effects of creatine. Amino. Acids. 2011;40(5):1271-1296.

20. Dalle-Donne I., Giustarni D., Colombo R., Rossi R., Milzani A. Protein carbonylation in human diseases. Trends Mol. Med. 2003;9(4):169176.

21. Zhang S. F., Hennessey T., Yang L., Starkova N. N., Beal M. F., Starkov A. A. Impaired brain creatine kinase activity in Huntington's disease. Neurodegener. Dis. 2011;8(4):194-201.

22. Genet S., Kale R. K., Baguer N. Z. Impaired brain creatine kinase activity in Huntington's disease. Mol. Cell Biochem. 2000;210(1-2):2328.

23. Li X. H., Chen Z., Gao Y. S., Yan Y. B., Zhang F., Meng F. G., Zhou H. M. Generation of the oxidized form protects human brain type creatine kinase against cystine-induced inactivation. Int. J. Biol. Macromol. 2011;48(2):239-242.

24. Liu Z. J., Zhou J. M. Spin-labeling probe on conformational change at the active sites of creatine kinase during denaturation by guanidine hydrochloride. Biochim. Biophys. Acta. 1995;1253(1):63-68.

25. Mu H., Zhou S. M., Yang J. M., Meng F. G., Park Y. D. Towards creatine kinase aggregation due to the cysteine modification at the flexible active site and refolding pathway. Int. J. Biol. Macromol. 2007;41(2):439-446.

26. Wang H. R., Bai J. H., Zheng S. Y., Wang Z. X., Zhou H. M. Ascertaining the number of essential thiol groups for the folding of creatine kinase. Biochem. Biophys. Res. Commun. 1996;221(1):174-180.

27. Zhou H. M., Tsou C. L. The presence of reactive $\mathrm{SH}$ groups in the enzymatically active dicyano derivative of creatine kinase. Biochim. Biophys. Acta. 1987;911(2):136-143.

28. Zhao T. J., Feng S., Wang Y. L., Liu Y., Luo X. C., Zhou H. M., Yan Y. B. Impact of intra-subunit domain-domain interactions on creatine kinase activity and stability. FEBS Lett. 2006;580(16):3835-3840.

29. Feng S., Zhao T. J., Zhou H. M., Yan Y. B. Effects of the single point genetic mutation D54G on muscle creatine kinase activity, structure and stability. Int. J. Biochem. Cell Biol. 2007;39(2):392-401.

30. Yatin S. M., Aksenov M., Butterfield D. A. The antioxidant vitamin E modulates amyloid beta-peptide-induced creatine kinase activity inhibition and increased protein oxidation: implications for the free radical hypothesis of Alzheimer's disease. Neurochem. Res. 1999;24(3):427-435. 